\title{
7. British and American monetarism compared
}

The spread of monetarism in the 1970s did not occur by a simple process of intellectual conquest. In most countries monetarist ideas could not be incorporated in policy formation until they had adapted to local economic conditions and recognized existing traditions of monetary management. Although the framework of financial control assumed some monetarist characteristics in virtually all the industrial nations, each nation still retained distinctive institutional arrangements and policy approaches. The UK posed a particular problem. With its long history of monetary debate and practice, and with its unusually well-established institutional structures, it did not readily assimilate Chicago School doctrines. Nevertheless, in the late 1970s and early 1980s the media, leading politicians and the public at large believed that British macroeconomic policy was becoming progressively more monetarist. Perhaps the apex of monetarist influence on policy came in the Budget of 1980 with the announcement of the MediumTerm Financial Strategy, in which targets for both monetary growth and the budget deficit were stated for four years into the future. In a statement to regional city editors on 9 June 1980, Mr Nigel (later Lord) Lawson, Financial Secretary to the Treasury (later to be Chancellor of the Exchequer), said that the 'Medium-Term Financial Strategy is essentially a monetary - or, if you like, monetarist - strategy'. ${ }^{1}$

The purpose of this essay is to compare the 'monetarism' referred to by Nigel Lawson with the 'monetarism' which is conventionally associated with the Chicago School. The monetarism which once dominated policy formation in the UK is called British monetarism, and the monetarism of the Chicago School, American monetarism. Of course, these simple labels are to a degree misleading. So many ideas have been in play, and they have undergone such constant evolution, that there is an inevitable arbitrariness in talking of this monetarism, that monetarism or the other monetarism. Despite the difficulties, a short description of British monetarism is ventured in the next section. No precise definition is given of American monetarism, but Friedman's work and Mayer's book on the structure of monetarism are taken as broadly representative. ${ }^{2}$ In the following four sections contrasts are drawn between British monetarism and American 
monetarism. The tensions between them were reflected in a number of perplexities which are critical to understanding the decline and fall of monetarism in UK policy formation in the mid-1980s. The final section therefore discusses, among other things, the corrosive impact of certain distinctively Chicagoan beliefs on the staying power of British monetarism in the policy debate.

It would be wrong to give the impression that there was a bitter transatlantic intellectual duel. The divergence between British and American monetarism certainly did not reflect a controversy as intense or long-standing as that between monetarism and Keynesianism. However, there were points of contact between the two debates. Perhaps it is not surprising, in view of the range of his work, that Keynes himself touched on several of the topics which have subsequently been disputed between American and British monetarists. As we shall see, the relationship between his views and the Anglo-American monetary disagreements of the 1980s turns out to be complex and ambivalent.

The opening months of 1980 , coinciding with the introduction of the Medium-Term Financial Strategy, have already been mentioned as a period of particular confidence in the virtues of monetary policy. Two official documents prepared at the time may be regarded as defining statements of British monetarism. The first is the March 1980 Green Paper on Monetary Control, which was the joint work of the Treasury and the Bank of England; the second is the Memorandum on Monetary Policy prepared by the Treasury for the Treasury and Civil Service Committee in June $1980 .^{3}$

The focus of both documents was a target for the growth of broad money, measured by sterling M3. Sterling M3 consisted of notes and coin and nearly all deposit liabilities of the banking system. (Certificates of deposit [CDs] were included, but both deposits and CDs with an original term to maturity of over two years were excluded. Sterling M3 was renamed M3 in May 1987.) Sterling M3 was not monitored for its own sake, but as an intermediate target thought to have a definite - if rather elusive - relationship with the ultimate target of inflation. The government's faith in this relationship was expressed strongly in the Treasury's Memorandum on Monetary Policy. While conceding that the mechanisms linking money and prices change over time and space, the Memorandum insisted that 'the proposition that prices must ultimately respond to monetary control holds whatever the adjustment process in the shorter term may be' ${ }^{4}$ An accompanying note on 'The stability of the income velocity of circulation of 
money supply' stated that, although velocity had fluctuated in the previous 17 years, 'at times quite sharply', there appeared to be 'a clear tendency for the series to return to the underlying trend'. ${ }^{5}$

If the monetary targets were to be achieved, it was essential to understand what caused monetary expansion. The favoured account of the money supply process gave pride of place to bank credit. With the deposit liabilities of the banking system representing the greater part of broad money, it was logical to attempt to limit the growth of bank assets. Since the growth of bank assets depended on the extension of new credit to the public, private and overseas sectors, monetary control was guided by an analysis of the so-called 'credit counterparts'. More specifically, the authorities used a credit counterparts identity which set out the relationship between, on the one hand, the public sector borrowing requirement, sales of public sector debt to non-banks, bank lending to the private sector and a variety of external and other influences, and, on the other hand, the growth of broad money. ${ }^{6}$

The chosen approach to managing monetary growth was therefore to operate on the credit counterparts. Bank credit to the public sector could be influenced by varying the PSBR and the amount of public debt sold to nonbanks; bank credit to the private sector was thought to be responsive to changes in interest rates; and bank credit to the overseas sector was related to intervention tactics on the foreign exchanges. ${ }^{7}$ In this spirit, the Green Paper on Monetary Control began with the observation that: 'There are a number of policy instruments available to the authorities in influencing monetary conditions. Of these the main ones are fiscal policy, debt management, administered changes in short-term interest rates, direct controls on the financial system and operations in the foreign exchange markets' ${ }^{8}$

Officials at the Treasury and the Bank of England had few illusions about the precision of monetary management by these means. Indeed, there was an uneasy slide from the use of the ambitious words 'control' in the title of the Green Paper to the more modest notion of 'influence' in the key opening paragraph. Nevertheless, the authorities were confident that, with their 'basic weapons', they could 'achieve the first requisite of control of the money supply - control, say, over a year or more'. ${ }^{9}$

Restraint over the budget deficit was seen as integral to monetary control over such annual periods. At Budget time a careful assessment was made of the consistency of the PSBR estimate with the broad money target, and the tendency of policy was to subordinate fiscal decision to the monetary targets. (As explained above on p. 119, the PSBR was renamed 'the public sector net cash requirement' [or PSNCR] in 1997.) In the early 1980s the humbling of fiscal policy was regarded as almost revolutionary, since it appeared to end the Keynesian demand-management role traditionally 
assigned to the government in post-war British political economy. The intention was not to vary the PSBR to counter cyclical ups and downs in the economy, but to ensure - in the words of the Treasury Memorandum that 'the trend path' of the PSBR be 'downwards'. ${ }^{10}$

If the authorities were sceptical about their ability to target broad money over short-run periods of a few months, the government was reluctant to make exact predictions about how long it would take for inflation to respond to monetary restraint. The emphasis was very much on the medium-term nature of the commitment to monetary targets. It was readily conceded that a check to broad money this year would be followed by slower inflation not in the immediate future, but in two, three or perhaps even four years' time. This was, of course, consistent with the belief that the relationship between broad money and inflation was medium-term in character. One consideration thought particularly likely to confuse the money/inflation link in the UK was the influence of a powerful trade union movement on wages and prices. This influence was sometimes regarded as having autonomy from strictly economic variables, such as the state of demand and the level of unemployment. The size of the public sector, and its insensitivity to monetary conditions, was a special problem. ${ }^{11}$

To ask what Keynes would have thought about British monetarism, in its 1980 version, may seem an ahistorical impertinence. However, it is not farfetched to see similarities between the system of monetary management envisaged by the Thatcher government in its early years and the idea of a managed currency advocated by Keynes throughout his life. Indeed, in one particularly interesting respect they coincided. The proposal for a managed currency was first made in A Tract on Monetary Reform (published in 1923), which was intended as a reasoned polemic against the gold standard. It contrasted the gold standard ('a barbarous relic') focusing on the stability of foreign exchange, and a managed currency ('a more scientific standard') with its goal of 'stability in an index number of prices'. ${ }^{12} \mathrm{~A}$ preference for domestic price stability over a fixed exchange rate was also embodied in the Medium-Term Financial Strategy, as originally formulated. In the 1981 Mais lecture Sir Geoffrey Howe, the Chancellor of the Exchequer, remarked that, if monetary targets had been adopted, 'you cannot have it both ways and also hold the exchange rate at a particular level. If any inconsistency emerges, the monetary targets have to come first' ${ }^{13}$ In accordance with this prescription exchange intervention was minimal for several years in the early 1980s.

In summary, British monetarism could be said to have four distinctive features: (1) the selection of broad money as the appropriate intermediate target, and a consequent emphasis on the control of bank credit as the central task of monetary management; (2) as part of the overall control of 
credit, a belief that fiscal policy should be made consistent with monetary policy and lose the demand-management functions attributed to it in the 1960s and early 1970s; (3) an admission that the link between money and inflation was medium-term in nature and difficult to predict, partly because of the strength of British trade unionism; and (4) the avoidance of any specific exchange rate objective, for reasons which Keynes would probably have understood and approved.

The first area of disagreement between British and American monetarism lay in the relative emphasis placed on broad and narrow money, and in related questions about the implementation of monetary control. As we have explained, in Britain in the early 1980s broad money was the focus of policy-makers' attention. Although Friedman himself believed that all measures of money conveyed a valuable message (and had blessed broad money in the classic A Monetary History of the United States he wrote jointly with Anna Schwartz), there is no doubt that the majority of American monetarists favoured the monetary base or a narrow money aggregate as the best policy indicator. According to Mayer, the monetary base was chosen for two reasons. One was that the American monetarist's 'analysis of the money supply process' told him that this was 'the variable which best reflect[ed] monetary policy actions'; the other was that he believed 'the monetary base to be the best indicator of future changes in the money stock'. ${ }^{14}$ Both aspects of Mayer's statement are important and need to be discussed, but to understand them a sketch of the American monetarists' view of the money supply process is required.

American monetarists, like their British counterparts, normally included bank deposits in their definition of the money supply. ${ }^{15}$ Since banks (in the 1980s and now) have to be able to repay deposits with cash, they are obliged to hold a fraction of their assets in the form of cash or balances with the central bank. According to American monetarism, empirical investigation was said to demonstrate a reasonably stable ratio between cash and deposits over the long run, while the quantity of cash - a liability of the central bank - was fully under the monetary authorities' control. It was therefore claimed that changes in the quantity of cash, reflecting central bank operations, determined the level of bank deposits and, hence, of the money supply. Cash (that is, notes, coin and balances with the central bank) is also known as 'high-powered money', the 'monetary base' or the 'reserve base'. Economists who believed in this account of the money supply process tended also to favour deliberate variations in the quantity of cash 
as the main instrument of monetary policy. This system, known as monetary base control, was widely advocated by American monetarists. (A version of monetary base control was indeed implemented, briefly and rather reluctantly, by the Federal Reserve in a three-year experiment from 1979 to 1982 .)

The first part of Mayer's statement is therefore readily explained. Changes in the monetary base were taken, by American monetarists, as the clearest guide to what the central bank had been doing, and so to the intended thrust of monetary policy. It is clear - from the previous section that the approach of British monetarists was quite different. With bank deposits viewed as the counterpart to bank credit, British monetarists concentrated their attention on variables believed to be relevant to the behaviour of bank credit. By far the most important of these was the short-term rate of interest, set by Bank of England operations in the money market. The contrast with the American monetarist position, with its concern over the quantity of reserves rather than the price at which they were made available to the banking system, was radical. Moreover, whereas in British monetarism the level of bank lending to the private sector was seen as critical to the monetary outlook, American monetarists were largely indifferent to it.

Some doctrinal purists might protest at this stage that a preference for the interest rate over the monetary base cannot plausibly be attributed to monetarists of any kind, not even to 'British monetarists'. They might say that, if that is the implication of the definition of British monetarism given here, the definition is too idiosyncratic and peculiar to be taken seriously. The answer to this objection is to recall the pattern of public debate in the early 1980s. The official policy framework prevailing at that time, and the attitudes informing it, were labelled as 'monetarist' in the media, in Parliament and in many other contexts. Furthermore, its emphasis on broad money and the credit counterparts arithmetic did logically entail that close attention be paid to interest rates. Of course, to say that interest rates mattered was not to make them a target of policy. On the contrary, the intention was that interest rates (the instrument) were to be varied to influence credit and money (the intermediate targets) in order to exert leverage over the inflation rate (the ultimate target).

American reaction to monetary control procedures in Britain varied from technical puzzlement to frank outrage. A consequence of the British arrangements was that official sales of gilt-edged securities to non-banks often had to be stepped up in order to reduce the excessive quantity of deposits created by bank credit. In other words, long-term funding was a basic instrument of monetary policy. An official at the Federal Reserve Bank of New York remarked at a conference in May 1982 that this 
'emphasis on selling intermediate and long-term securities to mop up money balances always sounds a bit strange to us'. ${ }^{16}$ Friedman's comments to the Treasury and Civil Service Committee in 1980 were much sharper. He expressed incredulity at the opening paragraph of the Green Paper on Monetary Control. In his view: 'Only a Rip Van Winkle, who had not read any of the flood of literature during the past decade and more on the money supply process, could possibly have written' the key sentence with its list of instruments for influencing monetary conditions. He judged that: 'This remarkable sentence reflects the myopia engendered by longestablished practices, the difficulty we all have of adjusting our outlook to changed circumstances.' He declared strong support for direct control of the monetary base instead of the British system. ${ }^{17}$

The dismay that many American monetarists felt - and still do feel about the Bank of England's monetary control procedures did not go unnoticed in the UK. Several economists advocated that Britain adopt some form of monetary base control. The most notable were Professor Brian Griffiths of the City University (later to be head of the Prime Minister's Policy Unit at 10 Downing Street), Professor Patrick Minford of Liverpool University and Professor (later Sir) Alan Walters who was appointed the Prime Minister's Economic Adviser in 1981. As all three are British and have been called monetarists, it may seem odd that in this paper 'British monetarism' is associated with broad money, credit control and funding. It perhaps needs to be repeated that British monetarism is defined here as the system of macroeconomic management established in the late 1970s and early 1980s, not a set of beliefs held by self-professed monetarist economists. In the end the views of Minford and Walters became important as much because they challenged the existing policy framework as because they supported it.

What about the second part of Mayer's statement, that American monetarists followed the monetary base because it was 'the best indicator of future changes in the money stock'? It may or may not be true that the monetary base had this property in the USA. (Much depends on the economists and technical econometric papers one decides to trust.) But in the UK, where the institutional apparatus is different, the monetary base is not and for several decades has not been - a reliable guide to future changes in the money stock on any definition. Under the British arrangements the Bank of England supplies cash in the required amounts to keep banks' balances at the daily clearing just adequate for them to fulfil their obligations. ${ }^{18}$ In consequence, the quantity of cash held by the banks adjusts to the size of their balance sheets rather than the other way round. The monetary base is - and long has been - determined by what is happening in the economy today; it does not determine what banks, the money stock or the 
economy will do in future. ${ }^{19}$ Indeed, one of the remarkable features of the British system is that - because of the flexibility of official money market operations - the banks can keep very low ratios of cash reserves to deposit liabilities. Since cash does not pay interest, this feature is attractive to profitseeking overseas bankers. (In the 1980s this was one reason for the intensity of foreign competition in the British financial system. Since then other countries have also reduced banks' cash reserve requirements and the scale of the UK's relative advantage has diminished.)

American economists did not appear fully to understand either the method of operation or the purpose of the British practices. The same Federal Reserve official who was puzzled by the significance of funding in the UK was also 'struck by the minimal role that reserve requirements play in the monetary control process'. He wondered whether 'the amount of leverage available' was 'sufficiently large for the central bank to pursue monetary and other policy targets effectively in all seasons'.$^{20}$ But the point of the British system was that - in contrast to the situation in the USA the quantity of cash reserves was not supposed to exert any leverage on the monetary targets. In his evidence to the Treasury and Civil Service Committee Friedman proposed some reforms which he thought would tighten the link between the base and the money supply. He noted that, in 1981, banks could hold a variety of assets to meet reserve requirements in the UK and suggested that:

It would be highly desirable to replace this multiple reserve system by one in which only a single asset - liabilities of the Bank of England in the form of notes and coin (that is, base money) - satisfies reserve requirements. This is probably the most important single change in current institutional arrangements that is required to permit more effective control of the money supply. ${ }^{21}$

But Friedman was confused between a $12^{1} \frac{1}{2}$ per cent reserve asset ratio which served an essentially prudential function and a $1 \frac{1}{2}$ per cent cash ratio which was the operational fulcrum of monetary policy. Since the confusion was shared to some degree by British economists and officials, it was perhaps excusable. But Friedman's imperceptiveness on the question reflected a wide gap between American and British approaches to monetary management and undoubtedly symptomized a certain amount of mutual incomprehension.

The differences between central bank techniques in the UK and USA are not new, but can be dated back to the early years of the Federal Reserve System. Unlike some recent participants in the debate, Keynes was well aware of their nature and origins, and devoted many pages of his Treatise on Money (published in 1930) to their analysis. He drew a contrast between 'the bank-rate policy' applied in Britain and the 'open-market policy' 
adopted in the USA. Essentially, the bank-rate policy involved a varying bank rate in order to control 'the aggregate of the central bank's assets', whereas open-market operations of the American kind produced 'a direct effect on the reserves of the member banks, and hence on the volume of deposits and of credit generally'. ${ }^{22}$ Although Keynes saw some merits in a bank-rate policy, it is quite clear that he preferred an open-market policy. He expressed great admiration for Governor Strong of the Federal Reserve, whom he regarded as the pioneer of scientific open-market operations, remarking that:

open-market operations can be so handled as to be quite extraordinarily effective in managing the currency. The successful management of the dollar by the Federal Reserve i.e. from 1923 to 1928 was a triumph - for the view that currency management is feasible, in conditions which are virtually independent of the movements of gold..$^{23}$

The sympathy here for the American approach connects with some of his later themes, since he also considered that, "whilst the bank rate may be the most suitable weapon for use when the object of the central bank is to preserve international equilibrium, open-market sales and purchase of securities may be more effective when the object is to influence the rate of investment'. ${ }^{24}$ This fitted in neatly with Keynes's emphasis in The General Theory on the need to influence investment in order to mitigate fluctuations in output and employment.

However, it should be noted that in The General Theory Keynes says rather little about central bank techniques and almost nothing about the Federal Reserve. There is a short comment, in the 'Notes on the trade cycle' in chapter 22, about how 'the most enlightened monetary control might find itself in difficulties, faced with a boom of the 1929 type in America, and armed with no other weapons than those possessed at the time by the Federal Reserve System'. ${ }^{25}$ But that is all. The implication seems to be that the severity of the American slump in the early 1930s, particularly by comparison with the mildness of the contemporaneous downturn in Britain, undermined the prestige of the Federal Reserve's procedures. Nevertheless, it is reasonable to conclude that - in this area of the technicalities of monetary control - Keynes inclined more towards American monetarism than British. In qualification, it also needs to be said that throughout this work Keynes referred repeatedly, and with evident belief in its importance, to 'credit', while in virtually all his discussions about monetary practice he was concerned about the behaviour of bank deposits and so of broad money. The focus on broad money was particularly obvious in his distinctions between income, business and savings deposits, and between industrial and financial 'circulations', in the first volume of the Treatise on Money. ${ }^{26}$ 


\section{III}

Basic to the Medium-Term Financial Strategy, and indeed to the monetarist enterprise in Britain more generally, was control over the fiscal position. Recognition of the importance of restricting public sector borrowing can be dated back to the mid-1970s, when extremely large budget deficits had been accompanied by difficulties in controlling the money supply and by fears that the substantial demands made by the public sector on the savings pool were crowding out private sector investment. Targets for the PSBR were included in the International Monetary Fund's Letter of Intent in December 1976, which set out conditions for its loan to the UK. In his speech to the Lord Mayor's dinner on 19 October 1978, Denis Healey - as Chancellor of the Exchequer in the then Labour government - said that the government was 'determined to control the growth of public expenditure so that its fiscal policy is consistent with its monetary stance'. ${ }^{27}$ The stipulation of precise numbers for the PSBR in the Medium-Term Financial Strategy from 1980 onwards should not be seen as a surprise innovation, but as the logical culmination to events over several years.

The thinking behind this approach was implicit in the credit counterparts arithmetic. If bank lending to the private sector, external influences on money growth and public sector debt sales to non-banks were all given, there was - and, of course, still is - a direct accounting link between the PSBR/PSNCR and the growth of the money supply. For every $£ 100$ million of extra PSBR there was an extra $£ 100$ million of M3. If an excessive PSBR threatened the monetary target, high interest rates would be needed to discourage lending to the private sector or encourage more buying of public sector debt. According to Peter Middleton (later to become Sir Peter and also Permanent Secretary to the Treasury), in a seminar paper given in the 1977/78 academic year, 'as a general proposition, a big fiscal deficit will tend to lead to a rapid growth of money supply and/or to higher interest rates . . . It follows that it is essential to examine fiscal and monetary policy simultaneously and coordinate them as far as practicable. 28

This relationship between flows of public sector borrowing and the growth of the money supply can be easily reformulated in terms of the stocks of public sector debt, bank lending to the private sector and money. ${ }^{29}$ The main conclusion is that, if the ratios of public debt and bank lending to gross domestic product are constant, a higher ratio of the PSBR to GDP is associated with a higher growth rate of broad money and so with more inflation. In practice, ratios of public sector debt and bank lending to GDP fluctuate substantially over time. But it is plausible that a government committed to extensive privatization of productive assets would favour, over the medium term, a rising ratio of private sector bank borrowing to 
GDP, rather than a high ratio of public debt to GDP. In the early 1980s that implied a need for the PSBR/GDP ratio to be maintained at a low level for several years.

What about the American monetarists' attitude towards fiscal policy? In the late 1960s there was a fierce debate in the USA - known as the 'Battle of the Radio Stations' after the initials of the main researchers involved (AM, FM, for Ando-Modigliani, Friedman-Meiselman) - about the relative effectiveness of fiscal and monetary policy. ${ }^{30}$ Arguably, it was the starting point of monetarism. Not only did it prompt Professor Karl Brunner to coin the term 'monetarist', but also it revolved around the idea later to become a commonplace in the British policy debate - that discretionary changes in fiscal policy were misguided as a means of influencing the economy.

In view of this background, American monetarists might reasonably have been expected to welcome the demotion of fiscal policy in the Medium-Term Financial Strategy. Curiously, that was not the reaction. Friedman, in his evidence to the Treasury and Civil Service Committee, said that the attention paid to the PSBR targets was 'unwise', partly 'because there is no necessary relation between the size of the PSBR and monetary growth'. ${ }^{31}$ Friedman's remarks were picked up by British critics of monetarism, notably by the Oxford economist, Christopher Allsopp, who was emboldened to claim that: 'The standard monetarist line is that it is only the money supply that matters for inflation control, and that fiscal policy has little direct effect on the economy, or on the ease or difficulty of controlling money. ${ }^{32}$ Although Friedman may have been particularly forthright in denigrating the place of PSBR control in British monetarism, there is no doubt that most American monetarists did not integrate fiscal policy into their thinking and policy advice. Thus a prescription for fiscal policy does not figure in Mayer's list of key monetarist propositions. The explanation might perhaps be sought in the separation of powers between the Federal Reserve (responsible for monetary policy) and the Treasury (which, along with other agencies, controls the Budget) in the American system. For these institutional reasons it made less sense to attempt to coordinate fiscal and monetary policy in the American macroeconomic context than in the British.

\section{IV}

There was never any pretence in British monetarism that $x$ per cent growth of broad money over the next year would be followed by an exactly predictable $y$ per cent growth of money GDP at an exactly known date in 
the future. It was readily admitted that the link between money and inflation was imprecise, while there were no illusions that the impact of monetary restraint on inflation would assert itself - or even be identifiable over periods of time as short as three to six months. Instead, the connection between broad money and the price level was regarded as rather difficult to forecast and essentially medium-term in nature. When British monetarism was at its most influential, policy-makers probably thought in terms of an $x$ per cent rate of broad money growth leading to an inflation rate of $x$ plus or minus 2 or 3 per cent at some date two to four years away. That may sound too flimsy as a basis for decision-taking; but it is vital to remember the context in which British monetarism first made headway in the public debate. In the mid-1970s, when the inflation rate was frequently at about 20 per cent or more, politicians were less fussy about an annual error in forecasting inflation equivalent to 2 or 3 per cent of the index than they are in the early twenty-first century. Moreover, in the early 1980 s there was little respect for computer-based macroeconomic forecasting methods which aspired to great exactitude. Such methods had totally failed to predict the scale of the inflationary retribution for the monetary policy mistakes of the Heath-Barber period.

American monetarists also refused to make bold claims about the precision of monetary impacts on the economy. Friedman coined an often repeated phrase when he said that the relationship between money and inflation was marked by 'long and variable lags'. In his evidence to the Treasury and Civil Service Committee, he cautioned that 'failure to allow for lags in reaction is a major source of misunderstanding'. After suggesting that 'for the US, the UK and Japan, the lag between a change in monetary growth and output is roughly six to nine months, between the change in monetary growth and inflation, roughly two years', he immediately inserted the qualification that, 'of course, the effects are spread out, not concentrated at the indicated point of time'. ${ }^{33}$ Arguably, this reluctance to be specific reflected an aspect of monetarism highlighted by Mayer, a preference for small reduced-form models over large-scale structural models of the economy. According to Mayer, monetarists believed that the money supply affected the economy in so many ways that 'even a large structural model is not likely to pick them all up' ${ }^{34}$

The differences between American and British monetarists in this area may not, therefore, seem to be all that wide. Keynes also recognized, although with reservations, the medium- and long-term validity of the money/inflation link. In chapter 21 of The General Theory, he said that the question of the relationship between money and prices outside the short period is 'for historical generalizations rather than for pure theory'. He continued by observing that, if liquidity preference (that is, the demand for 
money) tends to be uniform over the long run, 'there may well be some sort of rough relationship between the national income and the quantity of money required to satisfy liquidity preference, taken as a mean over periods of pessimism and optimism together' ${ }^{35}$ This is an interesting quotation because it shows that Keynes never dismissed the relevance of money to the long-run behaviour of prices, not even after the refinement of his theoretical ideas on the short-run determination of output in The General Theory. However, the section which contains the quotation also makes several references to wages and productivity as fundamental influences on prices. Keynes may have been reluctant to give a wholehearted endorsement to either a monetary or a wage-bargaining theory of the price level. Perhaps he thought that both had something to say.

Keynes's equivocation on the subject may have reflected the central position of the trade unions in British society. A strong and influential trade union movement continued for most of the first 50 or so years from the publication of The General Theory and obliged economists in the UK to pay trade unionism more attention than their counterparts in the USA. Not surprisingly, therefore, greater anxiety in the UK about the trade unions' impact on the labour market and the economy differentiated American and British monetarism, although the differences were more matters of emphasis than of substance. British monetarists were more prone to claim that trade unions, by disrupting the setting of marketclearing wages, aggravated the problem of unemployment. This argument was integrated into a specifically monetarist framework by saying that trade union activity increased the natural rate of unemployment. The point was that, in a situation such as the UK's where there had traditionally been strong political pressures to reduce unemployment below the natural rate, inflation expectations were contaminated by occasional phases of excess demand. As long periods of unemployment above the natural rate were then needed to remove the inflationary virus, and as these always involved restrictive and unpopular monetary policies, trade union activism indirectly stigmatized the deliberate use of monetary policy. British monetarists therefore accorded trade unions a more prominent and active role in the inflationary process than American monetarists. ${ }^{36}$

Friedman's position on the trade unions was that they could alter relative wages (that is, the ratio between union and non-union wages), but could not influence the absolute level of wages (that is, union and nonunion wages combined) which was determined by, among other things, the money supply. Moreover, a given amount of trade union power could not explain continuing inflation. When asked at an Institute of Economic Affairs lecture in 1974 whether trade unions could increase the natural rate of unemployment, Friedman acknowledged that this was 'a very difficult 
question to answer', but reiterated that 'what produced . . . inflation is not trade unions, nor monopolistic employers, but what happens to the quantity of money'. 37

The problem posed by trade unionism for British monetarism was exacerbated by the dominance of trade unionism in the public sector. While there are reasonably obvious transmission mechanisms between monetary policy and private sector inflation, it is far from evident how monetary policy affects the public sector. Wages and prices in government and nationalized industries are typically set by administrative fiat, and are sometimes remote from market forces. One exercise on the demand for money in the UK recognized this by regressing the money supply on private sector GDP, not GDP as a whole. ${ }^{38}$ It did not occur to American monetarists - with the USA's small government sector and weaker trade unions - to be so fastidious.

\section{V}

The British economy also differed (and still differs) from the American in being smaller and more susceptible to international influences. Since this difference made British monetarists more concerned about external pressures on domestic monetary policy than their American counterparts, it stimulated a lively debate about the appropriateness of alternative exchange rate regimes. This debate has continued over many decades, with Keynes's argument for a managed currency in A Tract on Monetary Reform being one of the most seminal contributions. Indeed, it could be claimed that when Sir Geoffrey Howe expressed such a decided preference for monetary targets over a fixed exchange rate in 1981 he was echoing a famous passage in the Tract where Keynes set up an opposition between stability of prices and stability of exchange. In his words, 'If the external price level is unstable, we cannot keep both our own price level and our exchanges stable. And we are compelled to choose' ${ }^{39}$

In the mid-1970s, however, Mr Healey failed to choose one or the other. Some interest rate changes were motivated by external factors, some by domestic considerations and some by both. The result was rather unhappy not just intellectually, but also practically, with 1976 seeing the most prolonged and embarrassing sterling crisis in the post-war period. The monetarist commitment to floating exchange rates in the early 1980s can be interpreted largely as a reaction to the muddles of the first three years of Mr Healey's Chancellorship. But a number of key theoretical inputs also moulded the climate of opinion and need to be mentioned. They can be dated back to the late 1960s, when leading economic journalists - egged on by Professor Harry Johnson of the University of Chicago and the London 
School of Economics - thought that the abandonment of a fixed exchange rate would remove an artificial barrier to British economic growth. More immediately relevant in the late 1970s was work done by Laidler and Parkin at the Manchester Inflation Workshop. ${ }^{40}$

An episode in late 1977 is basic to understanding the clarity of the monetarist support for a floating exchange rate in 1980 and 1981. After the excessive depreciation of 1976 the pound revived in 1977, and for much of the year its rise was restrained by heavy official intervention on the foreign exchanges. (The Bank of England sold pounds and bought dollars, to prevent the value of the pound rising.) This intervention had the effect of boosting the money supply, which in consequence grew much faster than envisaged by the official target. The target was for an increase of 9 to 13 per cent in sterling M3 in the 1977/78 financial year, whereas the actual result was an increase of 15.1 per cent. Monetarist economists argued that the high monetary growth jeopardized the financial progress achieved under the International Monetary Fund programmes and that, after the usual lag, it would be punished by higher inflation. More conventional economists at the Treasury and elsewhere thought that a 'low' exchange rate was needed for reasons of export competitiveness. The debate was conducted at several levels and is reported to have been particularly intense within the official machine.

When the government stopped intervening and allowed the pound to float upwards in October 1977, the monetarists seemed to have won. But their victory was not final. Although they were vindicated by a sharp upturn in inflation in late 1979 and early 1980 (after a fairly standard Friedmanite two-year lag), there were constant complaints that the government's permissive attitude towards the exchange rate allowed undue exchange rate appreciation. Among the most active participants to the 1977 debate were economists at the London Business School. On the whole they favoured adhering to the money supply targets and allowing the exchange rate to float. A particularly notable contribution was made by Mr Terry (later Lord) Burns, who was to become the government's Chief Economic Adviser in January 1980.41

The views of British monetarists in the late 1970s and early 1980s on the choice of exchange rate regime were not radically different from those of their American counterparts. One of the classic statements on the merits of floating was given by Friedman in his 1950 paper on 'The case for flexible exchange rates' ${ }^{42}$ This paper was perfunctory in its treatment of the impact of foreign exchange intervention on money growth, which was basic to the UK debate in the late 1970s. But its mood, with its aspersions on the forecasting ability of central bank officials and its praise for market forces, was close to that of the Thatcher government in its early years. In his evidence 
to the Treasury and Civil Service Committee in 1980, Friedman said that 'of course' an attempt to manipulate the exchange rate would limit the authorities' ability to control the money supply. He also criticized the government's announced policy of preventing excessive fluctuations in the exchange rate. In his opinion, 'this exception is a mistake; better to leave the market entirely free ... certainly for such a broad and efficient market as exists in British sterling' ${ }^{43}$

As it happened, the government in 1980 and early 1981 did not make an exception, even for a patently excessive fluctuation in the exchange rate. The pound became seriously overvalued, reaching $\$ 2.42$ in October 1980 compared to $\$ 1.63$ in October 1976, and in February 1981 almost 5 to the Deutschmark compared with 4 one year earlier. These exchange rate oscillations were subsequently singled out as the principal policy disappointment of the monetarist experiment. Inevitably, there has been much soul-searching about the suitability of monetary targets in a small economy subject to all the volatilities of contemporary international finance. It is interesting that Keynes, when describing the alternatives of price stability and exchange stability in the Tract, conceded that the right choice must 'partly depend on the relative importance of foreign trade in the economic life of the country'. ${ }^{44}$ Indeed, the book's final paragraph suggested that 'there are probably no countries, other than Great Britain and the United States, which would be justified in attempting to set up an independent standard'. Other countries could decide to peg their currencies to either sterling or the dollar until, 'with the progress of knowledge and understanding, so perfect a harmony had been established between the two that the choice was a matter of indifference'. ${ }^{45}$

\section{VI}

The period of strong monetarist influence over policy-making was shortlived, although its precise length is a matter for discussion and depends on whose version of events one selects. At one extreme it has been argued that broad money targets were discredited in July 1980 when the abolition of the 'corset' was followed by a jump of over 5 per cent in sterling M3 in only one month. (The corset was an artificial device for restricting credit, which imposed penalties on banks when their balance sheets increased faster than given percentage figures.) Officials quickly realized that the original sterling M3 target for the year to March 1981, which was for growth of between 7 and 11 per cent, was unattainable. They therefore sought forms of words to explain away - and, as far as possible, divert attention from - a serious monetary overshoot. In the end sterling M3 rose by 19.4 per cent in the 
1980/81 target period. This wide divergence from target, combined with the apparent failure of high interest rates to bring M3 back under control, is said by some authors to have caused monetarism to be abandoned only a few months after it had been publicly proclaimed as official dogma. ${ }^{46}$

However, a more plausible account would treat the erosion of the system set up in early 1980 as a gradual process. There are various possibilities, but mid-1985 is probably best regarded as the terminal phase. It was then that broad money targets, and hence the defining features of British monetarism, were scrapped. Just as monetarism did not gain ground by a simple process of intellectual conquest, so it did not retreat through a straightforward failure to meet key practical tests. Instead there were a number of distinct and intermittent challenges to monetarist arrangements. Although none of them individually might have been decisive, their cumulative impact was difficult to resist.

The first major problem was the pound's clear overvaluation in late 1980 and early 1981. The reasons for sterling's appreciation have been much debated, but one thesis - that above-target broad money growth obliged the government to maintain high interest rates, and high interest rates drove up the sterling exchange rate - had obvious cogency and relevance. As we have seen, both Sir Geoffrey Howe and Keynes had argued, in their different ways, that 'you cannot have it both ways', and simultaneously control the domestic price level and the exchange rate. But the experience of 1980 and 1981 suggested that Britain should try to have it both ways. It was better to have an intellectually muddled monetary policy than a politically unacceptable industrial recession. In 1982 and 1983 official thinking was that the exchange rate should have some role in assessing monetary conditions, while the monetary targets should be retained. After severe exchange rate overvaluation had caused a drastic fall in industrial production between mid-1980 and mid-1981, the government was less concerned about the logical niceties of the matter than about avoiding further damage to the manufacturing base.

The second difficulty was that sterling M3 proved awkward to manage. The 1980 Green Paper on Monetary Control may not have been particularly optimistic about month-by-month control, but at least it thought that sterling M3 could be brought within target 'over a year or more'. The large overshoot in 1980/81 undermined the credibility of even that rather unambitious statement. When there was another overshoot in the 1981/82 financial year, with sterling M3 up by 13 per cent compared to a target range of 6 to 10 per cent, many economists agreed with the then chief Opposition spokesman on Treasury and economic affairs, Peter Shore, that sterling M3 had become 'a wayward mistress'. There was a widely held view that sterling M3 was no longer a reliable intermediate target and that policy 
should be stated more flexibly. For those who still favoured monetary targets in some form, the disappointments with M3 targeting implied that monetary base control deserved more sympathetic consideration. The disillusionment with broad money was accompanied by increased interest in narrow money, either in the monetary base itself (also known as 'M0') or in M1 (cash in circulation with the public, plus sight deposits).

These changes in official allegiances and informed opinion, away from money targets to the exchange rate and from broad money to narrow money, were largely determined by the pattern of events. But intellectual rationalization was not far behind. A key figure in the dethronement of sterling M3 was Sir Alan Walters. Although his credentials when appointed as the Prime Minister's Economic Adviser in 1981 were avowedly 'monetarist', his monetarism was different in character from the 'British monetarism' described here. He had been much influenced by the American enthusiasm for monetary base control and was doubtful about the merits of operating on the credit counterparts to achieve broad money targets. His preference was for a measure of money used in transactions, which he thought was best approximated in the UK's case by M1. Despite problems because of institutional change, he believed that, 'It is money in this transactions sense that plays the central role in the theoretical structure and the propositions of monetarism'. He judged that credit had 'but a minor role' and was correspondingly sceptical about 'such credit magnitudes as M3'. (However, the Alan Walters of the mid-1980s was different from the Alan Walters of the early 1970s. He had been critical of the explosion of broad money during the boom of the early 1970s, emphasizing a connection between it and rapid asset price inflation. $)^{47}$

A consequence of the demotion of broad money was that less concern was felt about the rapid growth of credit in the private sector. Indeed, there was a school of thought - best represented by the Liverpool Research Group under Professor Patrick Minford - that bank lending to the private sector was always good for the economy, since it made possible more private sector spending and investment. High levels of lending were therefore welcomed, irrespective of the monetary repercussions. In some of its publications this group also suggested that large increases in broad money contained no inflationary threat. According to one issue of its Quarterly Economic Bulletin, credit - even credit in the form of bank lending - cannot be inflationary. Its argument was that, since borrowing by some individuals must be accompanied by lending by others, there is no net addition to or subtraction from wealth, and there should be no effect on behaviour. Thus, when both sides of a balance sheet increase: 'This is a straightforward portfolio adjustment and is not inflationary. ${ }^{\prime 48}$ Professor Minford, like Sir Alan Walters, had been much influenced by the American literature. As a 
reflection of this background, he regarded narrow money (particularly M0) as the most trustworthy money supply indicator and favoured monetary base control.

By 1983 and 1984 the views of Walters and Minford had been important in undermining the original monetarist arrangements. These arrangements suffered most from policy surprises and disappointments, and from criticisms from non-monetarist or frankly anti-monetarist economists. But the willingness of the two economists carrying the 'monetarist' label to repudiate certain aspects of the existing policy framework reinforced the suspicion and distrust with which British monetarism had always been viewed by the press, Whitehall and the majority of academic economists. Since Walters and Minford had undoubtedly been keen students of monetarist thought coming from the other side of the Atlantic, their susceptibility to its teachings meant that American monetarism contributed - if somewhat indirectly - to the decline of British monetarism. ${ }^{49}$

In another respect, however, Walters and Minford were loyal to the policy structure envisaged in 1979 and 1980. Although Walters promoted a 1981 report by Jurg Niehans, which identified sterling's sharp appreciation as a symptom of monetary tightness, he was adamantly opposed to attempts to manage the exchange rate by foreign exchange intervention. $\mathrm{He}$ wanted policy to be geared towards domestic monetary objectives and not towards the preservation of a fixed exchange rate or a target exchange-rate band. Indeed, he thought that these conditions still 'broadly' applied to the UK in 1985 when he wrote, in Britain's Economic Renaissance, that: 'The authorities announce that the level of short-term interest rates will depend primarily on the assessment of the movement in the monetary aggregates. The exchange rate is to be the object of benign neglect. ${ }^{50}$ Minford was equally hostile to systematic foreign-exchange intervention. In a paper first presented in 1980, he took it for granted that an 'independent monetary policy is possible' and noted that this 'presupposition is only valid under floating exchange rates'. ${ }^{51}$

Unlike the tendency to play down the significance of credit and broad money, the increasing official preoccupation with the exchange rate in the early and mid-1980s therefore cannot be ascribed to pressure from Walters and Minford, or to the influence of American monetarist ideas. In the end it was the completeness of the shift in official priorities from domestic monetary control to exchange rate stability which was primarily responsible for monetarism's downfall. Although several official statements had already hinted at the precedence of exchange rate stability as a policy goal, the Plaza Accord of September 1985 may have been the key turning-point. At the Plaza meeting the finance ministers of the five leading industrial nations decided that in future they should co-operate more actively to achieve an 
appropriate pattern of exchange rates. Thereafter the Chancellor of the Exchequer, Nigel Lawson, was constantly mindful of this international responsibility and gave less attention to domestic monetary issues.

Other considerations, more local and humdrum, pointed policy in the same direction. The standard British practice of long-term funding, which had so bewildered Federal Reserve officials in 1982, was beginning to cause technical problems in the UK's short-term money markets by mid-1985. The authorities decided that they could no longer 'overfund' the PSBR in order to keep broad money on target. Without this technique, which had proved immensely useful as a means of curbing the growth of the monetary aggregates, there were likely to be great difficulties meeting broad money targets. ${ }^{52}$ In addition to all the other supposed weaknesses of broad money, sterling M3 was now condemned for complicating the management of the money markets. In his Mansion House speech on 17 October 1985 Lawson suspended the broad money target for the 1985/86 financial year.

This was effectively the end of British monetarism. Although ostensibly only 'suspended', broad money targets had in fact been abandoned. A broad money target was announced in the 1986 Budget, but the envisaged growth rate was so high that it was not a worthwhile constraint on inflation. Despite that, the target was soon exceeded and Lawson suspended it again. By late 1986 the UK was in the early stages of a vigorous boom driven by extraordinarily rapid growth in bank lending and broad money. Although the government refrained from fiscal reflation, the credit and money excesses of 1987 and early 1988 were curiously similar to those seen in the Barber boom of the early 1970s. This was richly ironic, since the inflation which followed the Barber boom had been largely responsible for policy-makers' initial receptiveness to American monetarist ideas in the late 1970s.

The government did announce and observe narrow money targets, expressed in terms of M0, throughout 1986 and 1987. But, as its champions ought to have known, M0 tracks recent movements in money transactions and does not influence the future behaviour of the economy. The behaviour of narrow money completely failed to warn the government about the widening payments gap and rising inflation trend which emerged in late 1988. If Lawson had a meaningful anti-inflation policy in these years, the key instrument was the exchange rate for the pound and the central idea was that exchange rate stability would ensure rough equivalence between inflation in the UK and other industrial countries. As the dollar was falling heavily from early 1985 because of the USA's enormous trade and current account deficits, it seemed sensible to watch the pound/Deutschmark exchange rate more closely than the pound/dollar rate 
or, indeed, the effective exchange rate against a weighted basket of other major currencies. Throughout 1987 sterling was held fairly stable in a band of 2.85 to 3 Deutschmark.

This shadowing of the Deutschmark meant that the UK was virtually an associate member of the exchange rate mechanism of the European Monetary System. Lawson had opted for an external financial discipline in preference to the domestic focus associated with money supply targets. Since this was obviously a major change in strategy from the early years of the Thatcher government, an active public debate developed about the advantages and disadvantages of full EMS membership. Most academic economists approved of Lawson's new approach and thought it a welcome change from the doctrinaire monetarism he had espoused as Financial Secretary to the Treasury in 1980. But old-style monetarists (as they now were being called) were mostly hostile to EMS membership, while Walters and Minford were particularly outspoken in their attacks on it. In Britain's Economic Renaissance Walters described the EMS as 'rather messy' and remarked that the periodic exchange rate realignments, far from being determined in an economically rational way, were 'grand political events which present many opportunities for horse-trading, threats, counter threats, bluff, etc.' ${ }^{53}$ In his view, it would be best if the UK had nothing to do with it. In adopting this position, Walters was following the mainstream monetarist tradition, in favour of freely floating exchange rates, associated with Friedman and Johnson.

After Walters had persuaded the Prime Minister, Mrs Margaret (later Lady) Thatcher, that the EMS was a bad idea, she was increasingly worried about how Lawson was organizing monetary policy. Their private disagreements became steadily more acrimonious and eventually could not be hidden from the press or their Cabinet colleagues. On 7 March 1988 Margaret Thatcher indicated to the Bank of England her wish that foreign exchange intervention be more limited in scale. The pound soon appreciated sharply against the Deutschmark. However, this did not foreshadow a return to money supply targets. In the Budget on 15 March Lawson did not reinstate a broad money target and even narrow money received a sharp snub. The M0 target was rendered ineffective, if only temporarily, by the admission, in the Treasury's Financial Statement and Budget Report, that no specific action would be taken to correct an overshoot which was expected to emerge early in the coming financial year.

By mid-1988 economic policy was in a fairly standard British muddle. The monetarist framework, as understood in 1979 and 1980, had been coherent and relatively simple in conception. It had been replaced by a confused and eclectic pragmatism reminiscent of the Healey Chancellorship in the mid-1970s. Government policy involved 'looking at everything' 
(the exchange rate, bank lending, house prices and the trade figures) and decisions were often the result of a lucky dip between options suggested by events in the financial markets. The UK had dropped broad money targets of a kind favoured by British monetarists; it had not adopted monetary base control as recommended by American monetarists; it had had an unsatisfactory experience with narrow money targets supported by American-influenced monetarists such as Walters and Minford; and it had equivocated before rejecting, at least provisionally, full membership of the EMS.

The many fluctuations in policy fashion in the 1980s should not be allowed to disguise a number of successes which were clearly attributable to the original monetarist programme. Most obviously, the inflation rate was reduced from an average of almost 15 per cent in the late 1970s to about 5 per cent in the five years from 1982. In view of the substantial monetary overshoots in 1980/81 and 1981/82, this achievement may have seemed more due to serendipity than scientific management. But in all of the next three financial years the broad money target was met, and in early 1985 the annual growth of sterling M3 was down to under 10 per cent. Meanwhile the government broadly adhered to the fiscal side of the Medium-Term Financial Strategy. The result was that in the years of moderate growth from 1982 to 1986 the ratio of public sector debt to national output was falling, while in the Lawson boom of 1987 and 1988 tax revenues were so buoyant that the government actually ran a large budget surplus. The UK was therefore saved from the worries about long-run fiscal solvency which troubled some other European nations. ${ }^{54}$ The soundness of the UK's public finances was also, of course, in sharp contrast to the USA's problems with budget deficits throughout the 1980s. With the benefit of hindsight, fiscal issues seem to have been handled more prudently by British monetarists than their American counterparts..$^{55}$

Indeed, there is something of a puzzle about the government's - or, at any rate, Nigel Lawson's - decision in 1985 to scrap the monetarist machinery with which it (and he) had been so closely associated five years earlier. As we have seen, there were many pressures tending to undermine the monetarist approach throughout the early $1980 \mathrm{~s}$, but one central point could not be overlooked. Monetarism had accomplished most of the original objectives held by its supporters as set out in the key policy documents of 1979 and 1980. Why, then, had the monetarist approach to macroeconomic policy disintegrated so quickly? Perhaps the main solvents were the hostility of the traditional policy-making establishment, particularly academic economists in the universities, and the incomprehension of many influential commentators in the media. The aversion of the policy-making establishment may have had political roots. It is a safe 
sociological generalization that the majority of university teachers in Britain did not like Mrs Thatcher and did not in the 1980s (and do not now) vote Conservative. They are more sympathetic to socialism or the mixed economy than to competitive capitalism. It would be consistent if they disliked monetarism as much for the free-market evangelism of its high priests as for its technical content. Also important in explaining their attitudes was that British economists had become habituated to basing macroeconomic policy on external criteria, notably the exchange rate, instead of analysing domestic monetary conditions. Officials at the Bank of England, which for most of its history had been charged with keeping the pound stable in value against gold or the dollar, undoubtedly found it more natural to adjust interest rates in response to exchange rate movements than to deviations of the money supply from its target level. (The historical roots for policy-makers' preference for external, exchange-ratebased signals are discussed above in Essay 3 on 'Keynes, the Keynesians and the exchange rate'.)

In this context the debates between British and American monetarists were important. In the circumstances of the early 1980s, when monetarism was very much on trial, the new system needed to be defended with simple and convincing arguments by a cohesive group of advocates. Instead the arguments were typically of extreme complexity, while often they were more heated between rival members of the monetarist camp than between monetarists and non-monetarists. The differences between the British and American methods provided material and personnel for these disputes, and therefore weakened the monetarist position in public debate. Samuel Brittan of the Financial Times, the UK's most influential economic commentator at the time, referred dismissively on several occasions to 'monetarist mumbo-jumbo', well aware that most of his readers were bored by technicalities. To him, and to many other people, membership of the EMS - with its uncomplicated exchange rate disciple - had great appeal.

There is a paradox here. Many critics of monetarism assumed the label of 'Keynesian' and clearly believed that their views were in a direct line of descent from Keynes himself. But, as we have seen, this is questionable. One theme throughout almost all of Keynes's career was that monetary policy should be directed to the attainment of domestic policy objectives (price stability and full employment), not to fixing the international value of the pound (either in terms of gold or another currency). In 1923 he mentioned in A Tract on Monetary Reform, with evident approval and sympathy, 'the pioneer of price stability as against exchange stability, Irving Fisher'. ${ }^{56}$ It is intriguing that Irving Fisher is usually seen as an intellectual ancestor of Milton Friedman. But the determination of monetary policy by reference 
to domestic economic goals, and not to a numerically arbitrary exchange rate, was the central policy implication of Keynes's idea of a managed currency.

When Keynes wrote the Tract in 1923, Britain had extensive commercial influence throughout the world and its empire had an economic weight not much less than that of the USA. Its size relative to other countries justified it 'in attempting to set up an independent standard' as a complement to the dollar area. By contrast, in the late 1980s the UK was in a transitional and historically ambiguous position. It was no longer large enough to dominate a supra-national currency area, but it was not so small that membership of a European currency arrangement was self-evidently optimal. This dilemma, posed by the decline in British economic and financial power in the 65 years from the publication of the Tract, was basic to understanding policy-makers' resistance to a managed currency over the whole period. Perhaps the detailed blueprint for a managed currency would still have been unattractive if it had come not in the form of monetarism, but in a less ideologically unpalatable and far-reaching package. The trouble was that the Treasury and the Bank of England, knowing that the UK was in long-term financial retreat, lacked the self-confidence to make a managed currency work. American monetarists, coming from a large, self-contained economy, could more confidently recommend an ambitious and independent style of monetary policy than their British equivalents. It may always have been rather naïve to expect that ideas nurtured in the University of Chicago could be easily transplanted to Whitehall and Threadneedle Street.

At any rate, when the UK did eventually join the ERM (notionally as a stepping stone to the EMS) in October 1990, it was in the worst possible circumstances for the success of the enterprise. Intolerably high interest rates were needed to preserve the fixed rate with the Deutschmark. Home owners and small businesses were delighted by the drop in interest rates which followed the pound's expulsion from the ERM on 16 September 1992. The UK's association with the European fixed-exchange-rate system lasted less than two years, a shorter period than that of money-supply-target monetarism (from 1976 to 1985), and it was a fiasco. Since 1992 monetary policy has been guided neither by the exchange rate nor the money supply, but by a variety of indicators of which one - the output gap whose origins were discussed in the appendix to the Introduction - has probably been the most important. The UK has had a form of 'managed currency', although it is not the same as that proposed in the Tract on Monetary Reform and no one can know whether Keynes would have approved of how policy-making has evolved in the last 15 years. The Britain of the early twenty-first century is very different from that in which he lived. 


\section{NOTES}

1. HM Treasury press release, 9 June 1980, Statement by Nigel Lawson, MP, Financial Secretary to the Treasury during his meeting with regional city editors.

2. T. Mayer, The Structure of Monetarism (New York and London: Norton, 1978). See, particularly, p. 2 for a list of 12 characteristic monetarist propositions.

3. Monetary Control, Cmnd 7858 (London: HMSO, 1980), and Memorandum by HM Treasury, pp. 86-95, in vol. II, Minutes of Evidence of Third Report from the House of Commons Treasury and Civil Service Committee, Session 1980-81 (London: HMSO, 1981).

4. Memorandum by HM Treasury, p. 90 .

5. Note by HM Treasury on 'The stability of the income velocity of circulation of money supply', pp. 126-7, in Third Report from the Treasury and Civil Service Committee, Session $1980-81$.

6. For an example of the approach see the chapter on 'Bank lending and monetary control' in C.A.E. Goodhart, Monetary Theory and Practice (London, Macmillan: 1984), pp. $122-45$.

7. It should be added that interest rate changes acted not only on bank lending, but also on the ability of the authorities to sell gilt-edged securities as part of the funding programme.

8. Monetary Control, p. 1.

9. Monetary Control, p. 2.

10. Memorandum by HM Treasury, p. 89 .

11. See, for example, J. Burton, 'Trade unions' role in the British disease: "An interest in inflation"', pp. 99-111, in A. Seldon (ed.), Is Monetarism Enough? (London: Institute of Economic Affairs, 1980), particularly pp. 105-6; and T.G. Congdon, 'Why has monetarism failed so far', The Banker (April 1982), pp. 43-9. The subject was also discussed in T.G. Congdon, Monetarism: An Essay in Definition (London: Centre for Policy Studies, 1978), particularly pp. 53-6.

12. J.M. Keynes, A Tract on Monetary Reform (1923), reprinted in The Collected Writings of John Maynard Keynes, vol. IV, eds D. Moggridge and E. Johnson (London: Macmillan for the Royal Economic Society, 1971), p. 126, p. 132 and p. 138. See Essay 3, pp. 61-3, for a more extended discussion of Keynes' proposal for a 'managed currency'.

13. HM Treasury press release, 12 May 1981. The Mais Lecture given by Sir Geoffrey Howe, QC, MP, Chancellor of the Exchequer, at the City University, p. 11. At about this time Howe's Treasury colleague and future Chancellor, Nigel Lawson, became convinced that an exchange-rate discipline in the form of the EMS was superior to 'targets for domestic monetary aggregates' in monetary policy-making. On 15 June 1981 he sent Howe a long note on the virtues of joining the EMS. (Nigel Lawson, The View from No. 11 [London: Bantam Press, 1992], p. 111.)

14. Mayer, Monetarism, p. 27.

15. Few economists would regard the monetary base by itself as constituting a measure of the money supply. The Treasury was therefore rather iconoclastic in its attitude toward $\mathrm{M} 0$, which it apparently regarded as the full-scale aggregate when $\mathrm{M} 0$ was introduced in 1983. In both the USA and the UK the value of transactions in cash is less than 1 per cent of all transactions by non-bank agents.

16. The quotation comes from p. 71 of P. Meek, 'Comment on papers presented by Messrs. Forece and Coleby', in P. Meek (ed.), Central Bank Views on Monetary Targeting (New York: Federal Reserve Bank of New York, 1983), pp. 70-71.

17. The quotations are from p. 57 of M. Friedman, 'Response to questionnaire on monetary policy', in House of Commons Treasury and Civil Service Committee (Session 1979-80), Memorandum on Monetary Policy (London: HMSO, 1980), pp. 55-62. The selfconfidence and assertiveness of Friedman's criticism of the UK authorities in 1980 looks misplaced, to say the least, in retrospect. At the time of writing (mid-2006) no central bank tries to target the quantity of money by controlling the monetary base. In Goodhart's words, writing in 1995 , 'the debate over monetary base control appears 
historical'. (The quotation is from C. Goodhart, The Central Bank and the Financial System [London: Macmillan, 1995], p. 261.) See also pp. 235-6 of Bindsell's Monetary Policy Implementation: Theory, Past and Present for critical comments on Friedman's position in the early 1980s. (Ulrich Bindsell, Monetary Policy Implementation: Theory, Past and Present [Oxford: Oxford University Press, 2004].)

18. The arrangements are described in 'The role of the Bank of England in the money market', in The Development and Operation of Monetary Policy 1960-83 (Oxford: Oxford University Press for the Bank of England, 1984), pp. 156-64.

19. Econometric work may identify a contemporaneous link between the monetary base and one or other measure of the money supply, but that does not mean that the base 'explains' money rather than the other way round. If one wanted to predict the growth of M3 over the next six to 12 months, the level of monetary base today would not be much help, but forecasts of bank lending and the PSBR would be.

20. Meek, 'Comment', p. 70.

21. Friedman, 'Response', p. 58.

22. J.M. Keynes, A Treatise on Money: 2. The Applied Theory of Money (1930), reprinted in Collected Writings, vol. VI (1971), pp. 224 and 225.

23. Ibid., p. 231.

24. Ibid., p. 225.

25. J.M. Keynes, The General Theory of Employment, Interest and Money (1936), reprinted in Collected Writings, vol. III (1973), p. 327.

26. Keynes, Treatise 2, in Collected Writings, vol. V (1971), pp. 30-32 and pp. 217-30. These distinctions anticipate the more celebrated analysis of the motives for holding money in The General Theory.

27. HM Treasury press release, 19 October 1978. Speech by Rt Hon. Denis Healey, MP, Chancellor of the Exchequer, to the Lord Mayor's dinner.

28. The quotation is from p. 97 of P.E. Middleton, 'The relationship between fiscal and monetary policy', in M.J. Artis and M.H. Miller (eds), Essays in Fiscal and Monetary Policy (Oxford: Oxford University Press, 1981), pp. 95-116.

29. See pp. 21-3 of T.G. Congdon, 'The analytical foundations of the Medium-Term Financial Strategy', in M. Keen (ed.), The Economy and the 1984 Budget (Oxford: Basil Blackwell for the Institute of Fiscal Studies, 1984), pp. 17-29.

30. Mentioned on p. 5 of J.L. Jordan, 'The Anderson Jordan approach after nearly 20 years', Federal Reserve Bank of St Louis Review, October 1986, pp. 5-8.

31. Friedman, 'Response', p. 56.

32. The quotation is from p. 2 of C.J. Allsopp, 'The assessment: monetary and fiscal policy in the 1980s', Oxford Review of Economic Policy, vol. 1, no. 1, Spring 1985, pp. 1-19.

33. Friedman, 'Response', p. 59.

34. Mayer, Monetarism, pp. 24-5.

35. Keynes, General Theory, p. 306.

36. Thus, for example, Laidler's awareness of trade union power may have been one reason for his advocacy of a 'gradualist' approach to the elimination of inflation. See D. Laidler on the case for gradualism, in Laidler, Monetarist Perspectives (Oxford: Philip Allan, 1982), ch. 5, pp. 176-7.

37. M. Friedman, Unemployment versus Inflation? (London: Institute of Economic Affairs, 1975), pp. 30-35. The quotations are from pp. 32 and 33.

38. A. Budd, S. Holly, A. Longbottom and D. Smith, 'Does monetarism fit the UK facts?', in B. Griffiths and G.E. Wood (eds), Monetarism in the United Kingdom (London: Macmillan, 1984), pp. 75-119.

39. Keynes, Tract, p. 126.

40. See, for example, M. Parkin and G. Zis (eds), Inflation in Open Economies (Manchester: Manchester University Press and Toronto: University of Toronto Press, 1976).

41. See R.J. Ball and T. Burns, 'Long-run portfolio equilibrium and balance-of-payments adjustment in econometric models', in J. Sawyer (ed.), Modelling the International Transmission Mechanism (Amsterdam: North-Holland, 1979). It was Burns's position in the exchange rate controversy of $1977 / 78$, and his papers on the interrelationship between 
fiscal and monetary policy, which gave him a reputation as a monetary economist - or even as a monetarist - in the public debate and so led to his appointment as Chief Economic Adviser in January 1980. (See G. Howe, Conflict of Loyalty [London: Pan Books, 1994], p. 156.) In his paper on 'Exchange rate policy in the United Kingdom', in S. Holly (ed.), Money, Inflation and Employment: Essays in Honour of James Ball (Aldershot, UK and Brookfield, US: Edward Elgar, 1994), pp. 26-38, Budd highlights Ball's role in the 1977 debate. The final two sentences of Budd's paper read, 'The challenge was to incorporate the monetarist ideas into an empirical model of the UK economy. That is what Ball and his colleagues were able to do and that is why they played a major role in reshaping ideas and were able to contribute to a significant change in policy' (p. 37).

42. Reprinted in M. Friedman, Essays in Positive Economics (Chicago, IL: University of Chicago Press, 1953).

43. Friedman, 'Response', p. 53.

44. Keynes, Tract, p. 126.

45. Ibid., pp. 159-60.

46. G. Maynard, The Economy under Mrs Thatcher (Oxford: Basil Blackwell, 1988), p. 100.

47. A. Walters, Britain's Economic Renaissance (New York and Oxford: Oxford University Press, 1986), pp. 117 and 121. The description of M3 as a 'credit aggregate' was surprising. M3 consists of notes, coin and bank deposits. To say that its growth is driven by bank credit is not to say that bank deposits are the same thing as bank notes. (They evidently are not.) In any case, in the modern world where no money is backed by a commodity, the growth of M1 - or, indeed, even of M0 - is also driven by credit. (See T. Congdon, 'Credit, broad money and the economy', in D. Llewellyn [ed.], Reflections on Money [London: Macmillan, for the Economic Research Council, 1989], pp. 59-82.) Walters mentioned in a footnote on p. 118 of Britain's Economic Renaissance that he had used 'M3 statistics' to make an accurate prediction of 15 per cent inflation in 1974. See the footnote on p. 84 of T. Congdon, Money and Asset Prices in Boom and Bust (London: Institute of Economic Affairs, 2005) for more on Walter's shifting views on the money aggregates.

48. Liverpool Research Group in Macroeconomics, Quarterly Economic Bulletin, October 1987, p. 13. If this proposition were true, it would have drastic implications for economic theory and policy. But it overlooks the banks' liquidity-transformation role. Since cheques can be written against bank deposits and there is no loss of cheque-writing ability because of the existence of bank loans, the simultaneous expansion of deposits and loans increases the economy's liquidity and can change behaviour.

49. More direct damage to British monetarism came in other ways. For example, the Observer - which, under the lead of its Economics Editor, William Keegan, was strongly anti-monetarist - reprinted Friedman's 1980 evidence to the Treasury and Civil Service Committee. It correctly judged that this evidence would weaken the credibility of official policy. For the influence of the New Classical economist, Eugene Fama, on Minford's enthusiasm for M0, see note 37 to Essay 14 on p. 315 .

50. Walters, Renaissance, p. 135.

51. P. Minford, 'The exchange rate and monetary policy', in W.A. Eltis and P.J.N. Sinclair (eds), The Money Supply and the Exchange Rate (Oxford: Clarendon Press, 1981), pp. 120-42. The quotation is from p. 121 .

52. Again, see the chapter on bank lending and monetary control in Goodhart, Monetary Theory. On pp. 126 Goodhart noted that 'official reactions in the gilts market to developments in the monetary aggregates ... have been relatively successful in offsetting unforeseen variations' in bank lending and other influences on broad money growth.

53. Walters, Renaissance, pp. 128 and 131.

54. These worries, which were particularly serious in Italy, Ireland and Belgium, are discussed in chapters 1-3 of T. Congdon, The Debt Threat (Oxford: Basil Blackwell, 1988).

55. Perhaps it should not come as a surprise, after his remarks to the Treasury and Civil Service Committee in 1980, that Friedman should say in a letter to The Wall Street Journal on 4 September 1984 that he did not regard the USA's budget deficit - then about 4 per cent of GDP - as a major issue or a cause for concern.

56. Keynes, Tract, p. 147. 